UDC: 616.379-008.64: 612.112.7: 612.112.9

\title{
ANTIOXIDANT EFFECT OF EXTRACT OF YELLOW FRUITS OF CORNELIAN CHERRY (CORNUS MAS L.) IN RATS' LEUKOCYTES UNDER STREPTOZOTOCIN-INDUCED DIABETES MELLITUS
}

\author{
M. B. Seniv ${ }^{1}$, O. V. Dzydzan ${ }^{\circledR 1}$, I. V. Brodyak ${ }^{\star 1}$, \\ A. Z. Kucharska ${ }^{\mathbb{1} 2}$, N. O. Sybirna ${ }^{1}$ \\ ${ }^{1}$ Ivan Franko National University of Lviv, 4 Hrushevskyi St., 79005 Lviv, Ukraine \\ ${ }^{2}$ Wrocław University of Environmental and Life Sciences \\ 37/41 J. Chełmońskiego St., 51-630 Wrocław, Poland \\ *Corresponding author e-mail: iryna.brodyak@Inu.edu.ua
}

Seniv M.B., Dzydzan O.V., Brodyak I.V., Kucharska A.Z., Sybirna N.O. Antioxidant effect of extract of yellow fruits of cornelian cherry (Cornus mas L.) in rats' leukocytes under streptozotocin-induced diabetes mellitus. Studia Biologica, 2021; 15(1): 15-26 • DOI: https://doi.org/10.30970/sbi.1501.645

Background. The chronic hyperglycemia and intensified metabolic pathways of glucose conversion lead to the formation of excessive amounts of the reactive oxygen species and the development of oxidative stress under the condition of diabetes mellitus. In the recent decades, scientists have been searching for new drugs based on plant materials to prevent metabolic, structural and functional disorders in the body under diabetes. It has long been known that fruits and vegetables are sources of biologically active substances that have a beneficial effect on human health. The yellow fruits of the cornelian cherry (Cornus mas L.) contain a significant amount of substances (iridoids, phenolic acids and flavonoids), whose properties, biological effects and mechanism of action are not fully understood.

The aim of the study was to investigate the effect of the extract of yellow fruits of the cornelian cherry on the reactive oxygen species content and the activity of antioxidant enzymes in rats' leukocytes with streptozotocin-induced diabetes mellitus.

Materials and Methods. Experimental diabetes mellitus in rats was induced by intraperitoneal administration of streptozotocin. The development of diabetes mellitus was monitored by blood glucose level. From the $10^{\text {th }}$ day after the induction of diabetes, the animals were orally administered the extract of yellow fruits of the cornelian cherry at a dose of $20 \mathrm{mg} / \mathrm{kg}$ of the body weight for 14 days. On the last day of the experiment, we collected the blood into vials with heparin and isolated leukocytes to further determine the

( 2021 M. B. Seniv et al.; Published by the Ivan Franko National University of Lviv on behalf of Біологічні Студії / Studia Biologica. This is an Open Access article distributed under the terms of the Creative Commons Attribution License (http://www.budapestopenaccessinitiative.org and Creative Commons Attribution 4.0 License), which permits unrestricted reuse, distribution, and reproduction in any medium, provided the original work is properly cited.

ISSN 1996-4536 (print) • ISSN 2311-0783 (on-line) • Біологічні Студії / Studia Biologica • 2021 • Том 15 / № 1 • С. 15-26 
content of reactive oxygen species and the activity of antioxidant enzymes. Statistical analysis of the results was performed using MS Excel-2013.

Results. The content of the reactive oxygen species is increased and the activity of antioxidant enzymes is reduced in the rats' leukocytes during streptozotocin-induced diabetes mellitus. Oral administration of the extract of yellow fruits of the cornelian cherry to diabetic animals improves the antioxidant status of leukocytes, which is manifested in an increased activity of superoxide dismutase, catalase and glutathione peroxidase along with a decrease in the level of intracellular reactive oxygen species.

Conclusions. The extract of yellow fruits of the cornelian cherry (Cornus mas L.) restores the balance between prooxidants and antioxidant defense system in leukocytes of rats with streptozotocin-induced diabetes mellitus. Such results suggest that the extract of yellow fruits of the cornelian cherry might be one of the plant components in the development of new drugs that will correct metabolic and functional disorders in leukocytes under diabetes.

Keywords: extract of yellow fruits, cornelian cherry, diabetes mellitus, reactive oxygen species, antioxidant enzymes, leukocytes

\section{INTRODUCTION}

Type 1 diabetes mellitus (DM) is a polygenic multifactorial disease that causes the development of absolute insulin deficiency, impaired carbohydrate and subsequently lipid and protein metabolism [21]. Hypoinsulinemia and hyperglycemia lead to the development of oxidative stress due to increased glycation, glucose autooxidation, activation of polyol and hexosamine pathways, oxidative phosphorylation with intensification of the functions of the electron transport chain of mitochondria [32]. Oxidative stress leads to further adverse processes: increased cholesterol biosynthesis, increased lipid peroxidation and overproduction of free radicals, including reactive oxygen species (ROS), which, in turn, leads to a depletion of components of the antioxidant defense system [5, 11, 32].

Hyperglycemia and oxidative stress primarily affect blood cells and vascular endothelial cells. Changes in the structure and functional activity of blood cells are an important part of the pathogenesis of diabetic complications [32]. In particular, changes in the morphofunctional state of peripheral blood leukocytes [30, 31] can be explained by a violation of the physiological balance between the level of antioxidants and free radicals [32]. Physiological levels of intracellular ROS are crucial for the migration of leukocytes from the blood to the area of inflammation, where they perform their main functions as immunocompetent cells [29]. Hyperproduction of ROS in leukocytes leads to multiple pathological changes in signaling and metabolic pathways, disorders of cells and organs homeostasis under the condition of diabetes [5].

Therefore, it is important to investigate some remedies that could correct or eliminate the negative effects of free radical compounds and maintain glucose levels within the physiological range [4].

The sources of biologically active substances that have a beneficial effect on human health are fruits and vegetables. An example is the cornelian cherry (Cornus mas L.), whose fruits have anti-inflammatory, cardiac- and hepatoprotective, antibacterial and diuretic effects [18]. We have previously identified the antidiabetic and antioxidant

ISSN 1996-4536 (print) • ISSN 2311-0783 (on-line) • Біологічні Студії / Studia Biologica • 2021 • Том 15 / № 1 • C. 15-26 
effects of the extract of yellow fruits of the cornelian cherry under streptozotocin-induced diabetes [4]. However, there are no data on the effect of this extract on the morphofunctional state of blood leukocytes under the condition of diabetes.

The main aim of the study was to investigate the effect of the extract of yellow fruits of the cornelian cherry on ROS intracellular level and the activity of the antioxidant defense system's enzymes in peripheral blood leukocytes of rats with streptozotocininduced DM.

\section{MATERIALS AND METHODS}

Animal experiments. Wistar male rats with starting weight $130 \pm 5 \mathrm{~g}$ and aged 8-9 weeks were used in all experiments. Animals were kept in vivarium with standard conditions. Rats had free access to water and standard chow and were kept under a $12 / 12 \mathrm{~h}$ light/dark cycle. The room temperature and humidity were maintained automatically at about $22 \pm 2{ }^{\circ} \mathrm{C}$ and $60 \pm 5 \%$, respectively. All manipulations with animals were conducted in accordance with "General ethical principles of experimentation on animals" approved by the First National Congress on Bioethics (Kyiv, Ukraine, 2001) and the "European Convention for the Protection of Vertebrate Animals used for Experimental and Other Scientific Purposes" (Strasbourg, France, 1985). The bioethical examination of the experiments carried out at the Biological Faculty of the Ivan Franko National University of Lviv was executed in the form of a protocol No. 18-01-2021 of January 29, 2021.

DM was induced by a single intraperitoneal injection of rats with streptozotocin (Sigma-Aldrich, St. Louis, MO, USA) at a dose of $60 \mathrm{mg} / \mathrm{kg}$ b.w. Streptozotocin-treated rats with glucose levels over $12 \mathrm{mmol} / \mathrm{L}$ were considered as diabetic. Rats were divided into 3 groups containing 8 animals each: group 1 - control rats (healthy animals), group $2(D M)$ - rats with streptozotocin-induced DM, group $3(D M+Y C)$ - diabetic rats treated with extract of yellow fruits of the cornelian cherry (YC). Once daily for 14 days, rats received the following substances by gavage: Control and DM groups $-1 \mathrm{~mL} / \mathrm{rat}$ of water, group $D M+L A-1 \mathrm{~mL} /$ rat of aqueous solutions of $Y C$ at a dose of $20 \mathrm{mg} / \mathrm{kg}$ b.w. The dose and duration of administration were selected based on previous studies [4].

Plant materials, the procedures for preparation of the cornelian cherry extract, identification and quantification of compounds of the cornelian cherry extract by the UPLC-qTOF-MS/MS and HPLC-PDA methods were previously described by Dzydzan et al. [4].

Blood collection and isolation of leukocytes. At the end of the experimental period, rats of all groups were anesthetized using deep ether anesthesia and euthanized by decapitation. Blood was collected into vials with heparin. Leukocytes were isolated from blood by centrifugation over a gradient of ficoll-triombrast density. Then, the cells were washed three times with cold $\left(4^{\circ} \mathrm{C}\right)$ PBS. The total number of leukocytes was calculated manually using a counting chamber.

Leukocytes were lysed and lysates of leukocytes were centrifuged to remove cell debris [5]. Supernatants were collected and used for biochemical assays. The protein content in lysates of leukocytes was determined according to Lowry's method [13].

Quantification of ROS. Leukocytes were incubated with 2',7'-dichlorodihydrofluorescein diacetate $\left(\mathrm{H}_{2} \mathrm{DCFDA}\right)$ at $37^{\circ} \mathrm{C}$ for $30 \mathrm{~min}$ in the dark [5]. After incubation, leukocytes 
were washed twice with PBS and immediately analyzed using a fluorescence microscope (Nikon Optiphot 2, Japan). Fluorescence microscopic images were processed using Image J. The ROS production was calculated by dividing the total image 2',7'-dichlorofluorescein (DCF) fluorescent intensity by the total number of leukocytes and was expressed in DCF fluorescence/cell (a.u. - arbitrary unit).

Antioxidant Enzymes Assays. Superoxide dismutase (SOD) activity was determined according to the method described by Kakkar et al. [11]. The results were expressed as $\mathrm{U} / \mathrm{mg}$ of protein. One unit of SOD activity was defined as the amount of enzyme causing $50 \%$ inhibition of the reduction to formazan observed in the blank. Catalase (CAT) activity was estimated by the color intensity decreasing of the complex forming $\mathrm{H}_{2} \mathrm{O}_{2}$ with molybdenum salt [8]. One unit of CAT activity was expressed as $\mathrm{nmol}$ of $\mathrm{H}_{2} \mathrm{O}_{2} / \mathrm{min} \times \mathrm{mg}$ of protein. Glutathionperoxidase (GPx) activity was determined by the rate of oxidation of GSH before and after incubation of the sample with tertiary butyric hydroperoxide. The reduction of GSH was observed in the color reaction with DTNB [17]. GPx activity was expressed in $\mu \mathrm{mol} / \mathrm{min} \times \mathrm{mg}$ of protein. The activity of glutathione reductase (GR) was measured by the decrease in absorbance due to the oxidation of NADPH, which is required for the reduction of oxidized glutathione at $340 \mathrm{~nm}$ [7]. One unit of GR activity was calculated as one nmole of $\mathrm{NADPH} / \mathrm{min} \times \mathrm{mg}$ of protein. The concentration of GSH was expressed in $\mathrm{nmol} / \mathrm{mg}$ of protein.

Statistical Analysis. The results were calculated using Microsoft Excel 2013 and expressed as mean \pm standard error of the mean $(M \pm S E M)$. Analysis of the variance (ANOVA) followed by Tukey's post hoc multiple comparison test was used for data analysis and was performed in GraphPad Prism 8.0 (San Diego, California, USA). Differences between the groups were considered statistically significant at $P<0.05$.

\section{RESULTS AND DISCUSSION}

The effect of the extract of yellow fruits of the cornelian cherry on ROS content in the blood leukocytes of rats with streptozotocin-induced DM. Analysis of ROS content in leukocytes was performed using $2^{\prime}, 7^{\prime}$-dichlordihydrofluorescein diacetate $\left(\mathrm{H}_{2} \mathrm{DCFDA}\right)$, which is widely used as an indicator of oxidative stress. It penetrates the lipid bilayer and, consequently, can be used to detect ROS in living cells. $\mathrm{H}_{2}$ DCFDA is easily oxidized by ROS to fluorescent dichlorofluorescein product (DCF) [23].

Comparative analysis of the average values of leukocytes fluorescence allowed establishing a significant increase (1.5 times) in ROS content under diabetes compared with leukocytes of the control animals (Fig. 1A). Leukocytes, in particular neutrophils, are one of the main sources of ROS in the body under the condition of diabetes. This process is probably initiated through protein kinase C-mediated activation of NADPHoxidase in response to chronic hyperglycemia. NADPH-oxidase is a multicomponent, membrane-associated enzyme that catalyzes the one-electron reduction of molecular oxygen to the superoxide anion $\left(\mathrm{O}_{2}^{-*}\right)$ using reduced $\mathrm{NADP}^{+}$as an electron donor. Local release of ROS by leukocytes, in particular $\mathrm{O}_{2}^{-*}$, can potentially lead to damage of endothelial cells and adjacent tissues [9].

All these processes together enhance oxidative stress and intensify metabolic pathways of glucose conversion, which are also accompanied by overproduction of ROS. The main processes of ROS formation take place in mitochondria, electron transport chain (ETC), endoplasmic reticulum, and peroxisomes. ROS is formed by

ISSN 1996-4536 (print) • ISSN 2311-0783 (on-line) • Біологічні Студії / Studia Biologica • 2021 • Том 15 / № 1 • C. 15-26 
electron transfer in I and III ETC complexes in mitochondria. Production of ROS, primarily $\mathrm{H}_{2} \mathrm{O}_{2}$, also occurs in microsomes and peroxisomes. Immune cells, such as neutrophils and macrophages, have potent ROS-dependent mechanisms to fight foreign microorganisms [19].
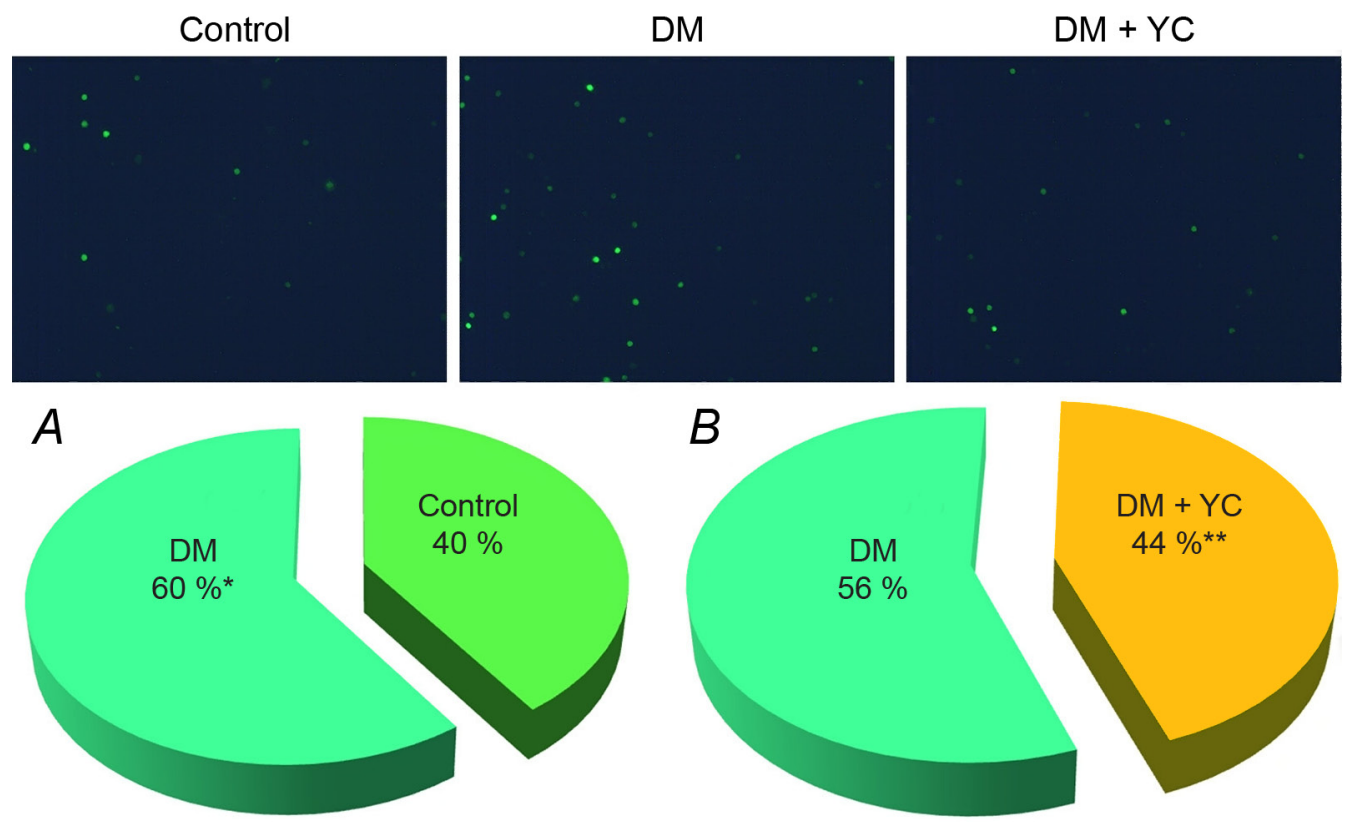

Fig. 1. Detection of ROS in peripheral blood leukocytes of rats: $(\boldsymbol{A})$ ROS level (average fluorescence intensity per cell in the field of view, digitized using GelPro software and expressed in \%) in blood leukocytes of control rats and rats with streptozotocin-induced diabetes (DM); (B) the effect of the extract of yellow fruits of the cornelian cherry $(Y C)$ on intracellular ROS level (\%) in leukocytes of rats with $\operatorname{DM}(n=8)$

Significance: ${ }^{*}-\mathrm{P}<0.05$ compared to the control group; ${ }^{* *}-\mathrm{P}<0.05$ compared to the DM group

Рис. 1. Детекція активних форм оксигену в лейкоцитах периферичної крові щурів: $(\boldsymbol{A})$ рівень активних форм оксигену (середня інтенсивність флуоресценції на одну клітину в полі зору, оцифрована за допомогою програмного забезпечення GelPro та виражена у \%) в лейкоцитах крові контрольних щурів та зі стрептозотоцин-індукованим цукровим діабетом; (B) вплив ектракту жовтих плодів дерену справжнього на внутрішньоклітинний рівень активних форм оксигену (\%) в лейкоцитах тварин із цукровим діабетом $(n=8)$

Примітка: * - Р < 0,05 - достовірність відхилення від значень у контролі; ** - P < 0,05 - достовірність відхилення від значень за цукрового діабету

Glucose autooxidation, redox imbalance, decreased concentration of endogenous antioxidants are the cause of ROS overproduction in diabetes, whereas the use of antioxidants of natural origin, including vitamins, bioflavonoids, carotenoids, etc., can prevent the development of oxidative stress. According to the fluorescence analysis, it was found that the administration of the extract of yellow fruits of the cornelian cherry to animals with streptozotocin-induced diabetes caused a 1.3 times decrease in the content of ROS in the rats' leukocytes (Fig. 1B). Chemical compounds present in the extract of yellow fruits of the cornelian cherry, are capable of ROS scavenging [20]. In particular, phenolic compounds neutralize free radical electrons, forming relatively stable phenoxyl radicals, and stop chain oxidation reactions [2]. 
The effect of the extract of yellow fruits of the cornelian cherry on the activity of antioxidant defense system's enzymes in blood leukocytes of rats with streptozotocin-induced DM. The generation of free radicals is not harmful to cells when the rate of their formation is equilibrated by elimination. An imbalance between ROS production and the ability of biological systems to detoxify them along with intermediates, or even repair damage, leads to the development of oxidative stress [19].

The intensification of ROS formation leads to a depletion of the antioxidants content and disruption of the antioxidant defense system enzymes [3, 5, 9]. Vitamins $A$, C, E, glutathione, enzymes (SOD, CAT, GPx and GR) are the most common antioxidants [15]. They have various mechanisms to counteract the excessive ROS accumulation. Intracellular antioxidants are localized in the mitochondrial compartment (thioredoxins, SOD, GPx) and in the cytosol [26]. Superoxide dismutase catalyzes the dismutation of the superoxide radical to hydrogen peroxide. Isoforms of SOD are localized in mitochondria (SOD2), cytoplasm and extracellular compartment (SOD1 and SOD3). Catalase is an enzyme that is localized in the peroxisome, catalyzing the conversion of hydrogen peroxide to water and molecular oxygen [26]. Glutathione peroxidase uses glutathione to reduce hydrogen peroxide and lipid hydroperoxides. The oxidized glutathione formed as a result of this reaction is converted into reduced glutathione by GR $[10,16,27]$. Therefore, the state of cell antioxidant system is one of the main indicators of the protective capabilities of the body.

It was found that the activity of enzymes of the antioxidant system is significantly reduced in the blood leukocytes of rats with diabetes (Table). Glycation of antioxidant enzymes in the conditions of hyperglycemia can lead to a disruption of their structure and, consequently, functioning $[3,10]$. A decrease in the activity of the studied enzymes may also be due to changes in the expression of their genes [22]. The active forms of oxygen and nitrogen can also directly disrupt the structure of molecules, in particular enzymes under the condition of oxidative stress $[3,6]$. As a result of hyperglycemia, the polyol pathway of glucose utilization is activated, which uses up to $30-35 \%$ of its cellular content. In this case, glucose is reduced to sorbitol by aldose reductase using reduced $\mathrm{NADP}^{+}$. The depletion of the concentration of reduced $\mathrm{NADP}^{+}$causes a impairment in the regeneration of oxidized glutathione to reduced glutathione, which is a substrate for GPx [12, 24, 25].

Activity of enzymes of antioxidant defense system in leukocytes of blood of control animals and rats with streptozotocin-induced DM (M $\pm S E M, n=8)$

Активність ензимів антиоксидантної системи захисту в лейкоцитах крові контрольних тварин і щурів зі стрептозотоцин-індукованим цукровим діабетом $(\mathrm{M} \pm \mathrm{SEM}, \mathrm{n}=\mathbf{8})$

\begin{tabular}{|c|c|c|}
\hline Enzymes $\quad$ Groups & Control & DM \\
\hline SOD, U/mg of protein & $11.63 \pm 0.73$ & $9.05 \pm 1.04^{*}$ \\
\hline CAT, $\mathrm{nmol} / \mathrm{min} \times \mathrm{mg}$ of protein & $28.86 \pm 2.43$ & $21.14 \pm 1.36^{*}$ \\
\hline GPx, U/mg of protein & $3.12 \pm 0.21$ & $2.37 \pm 0.23^{*}$ \\
\hline $\mathrm{GR}, \mathrm{nmol} / \mathrm{min} \times \mathrm{mg}$ of protein & $42.53 \pm 4.51$ & $32.64 \pm 2.68^{*}$ \\
\hline
\end{tabular}

Designations: * $-\mathrm{P}<0.05$ compared to the control group

Примітка: * $\quad$ $\quad$ 0,05 - достовірність відхилення від значень у контролі

ISSN 1996-4536 (print) • ISSN 2311-0783 (on-line) • Біологічні Студії / Studia Biologica • 2021 • Том 15 / № 1 • C. 15-26 
The administration of the extract of yellow fruits of the cornelian cherry to diabetic animals led to an increase in the activity of catalase (42 \%), SOD $(22 \%)$ and GRx $(24 \%)$ in blood leukocytes (Fig. 2). The obtained changes can be explained by a decrease in non-enzymatic glycosylation of proteins due to the manifestation of hypoglycemic properties of the studied extract [4]. The biologically active acids of the extract, in particular oleanolic acid contained in fruits of Cornus species, can enhance the release of acetylcholine, which, in turn, stimulates muscarinic M3 receptors in pancreatic cells. As a result, the release of insulin increases and glucose concentration decreases $[1,28]$.

A

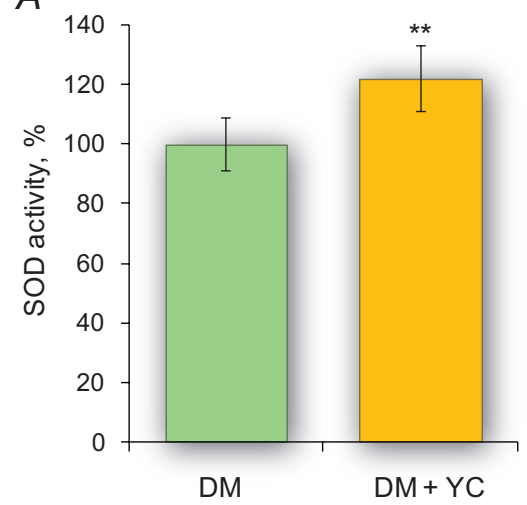

C

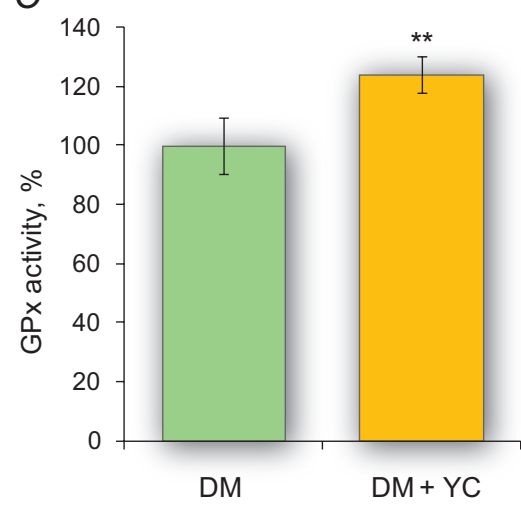

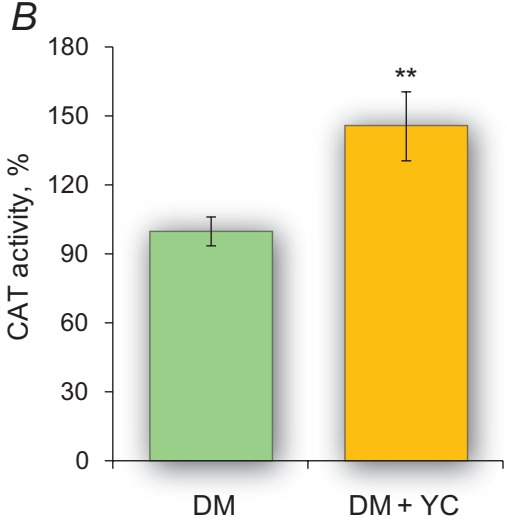

$D$

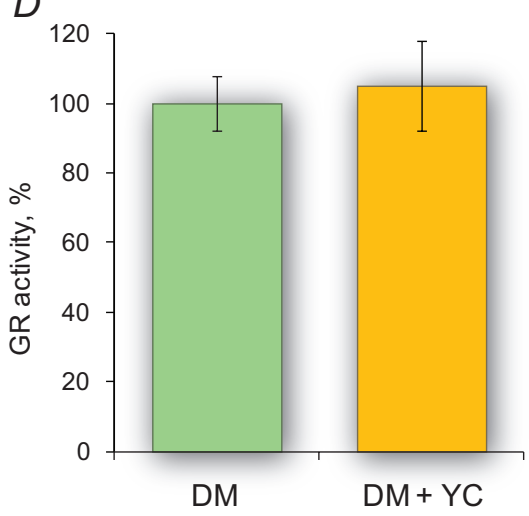

Fig. 2. The effect of the extract of yellow fruits of the cornelian cherry (YC) on the activity of antioxidant enzymes in leukocytes of rats with streptozotocin-induced DM: $(\boldsymbol{A})$ SOD, superoxide dismutase; $(\boldsymbol{B})$ CAT, catalase; $(\boldsymbol{C}) \mathrm{GPx}$, glutathione peroxidase and $(\boldsymbol{D}) \mathrm{GR}$, glutathione reductase. The results are shown as the mean \pm SEM

Designations: ** $-\mathrm{P}<0.05$ compared to the DM group

Рис. 2. Вплив екстракту жовтих плодів дерену справжнього на активність ензимів антиоксидантного захисту в лейкоцитах периферичної крові щурів зі стрептозотоцин-індукованим цукровим діабетом: (A) SOD, супероксиддисмутаза; (B) CAT, каталаза; $(\boldsymbol{C})$ GPx, глутатіонпероксидаза; $(\boldsymbol{D}) \mathrm{GR}$, глутатіонредуктаза. Результати представленні як $\mathrm{M} \pm \mathrm{SEM}(\mathrm{n}=8)$

Примітка: ** - P < 0,05 - достовірність відхилення від значень за цукрового діабету

Therefore, biologically active compounds of the cornelian cherry extract have a positive effect on the activity of defense system enzymes, reducing the negative impact of oxidative stress on the body (Fig. 3). 


\section{Yellow cornelian cherry fruits (Cornus mas L.)}

\section{Extract of yellow fruits of cornelian cherry}
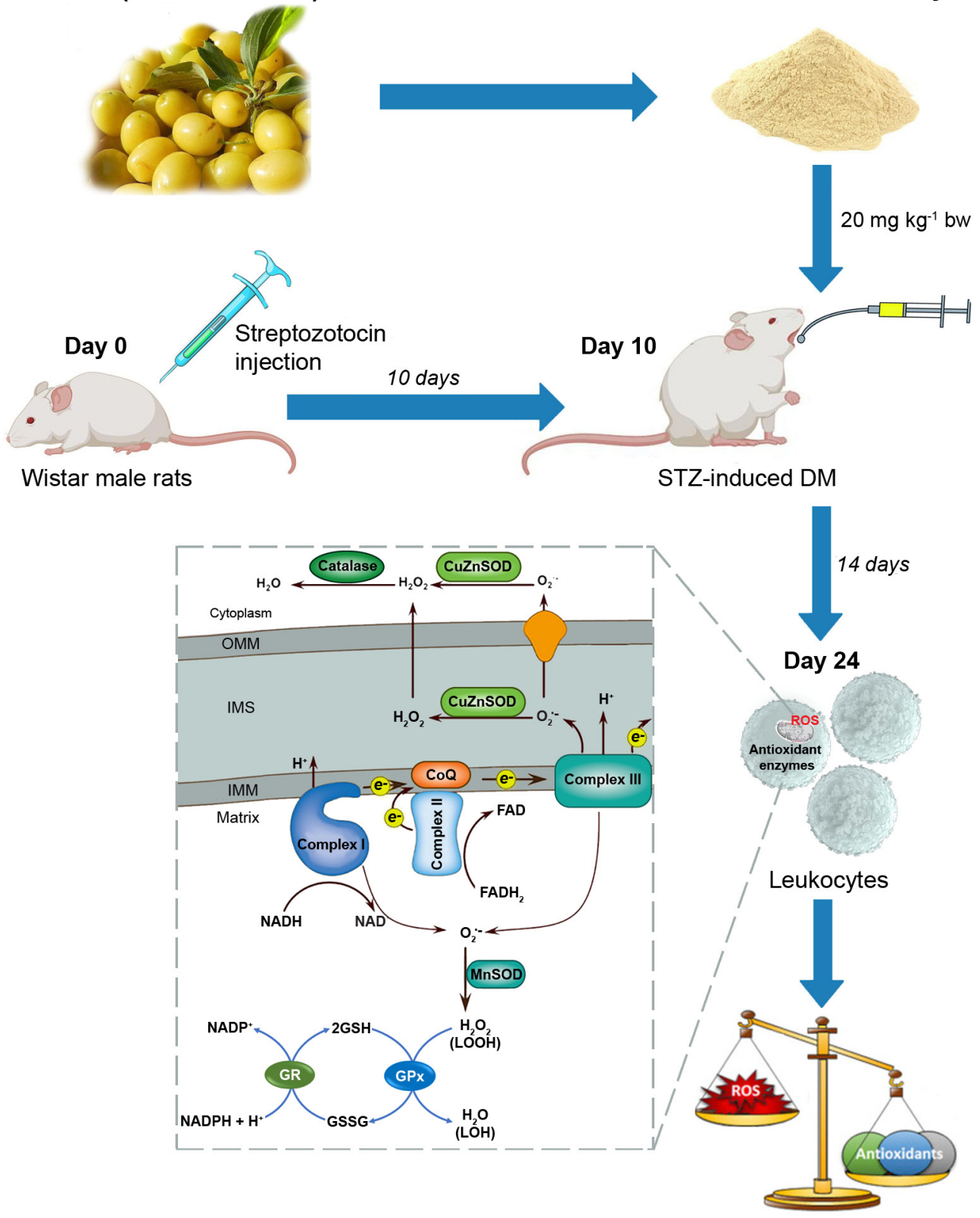

Fig. 3. The extract of yellow fruits of the cornelian cherry restores antioxidant balance in leukocytes of rats with streptozotocin-induced diabetes mellitus

Рис. 3. Відновлення антиоксидантного балансу в лейкоцитах щурів зі стрептозотоцин-індукованим цукровим діабетом за введення екстракту жовтих плодів дерену справжнього 


\section{CONCLUSIONS}

The biochemical changes and physiological symptoms under diabetes are tcaused by an impaired insulin secretion, which leads to a disruption in all metabolic pathways. In combination, all these processes lead to hyperglycemia and intensification of glucose metabolism, which are accompanied by the formation of excessive amounts of ROS. The administration of the extract of yellow fruits of the cornelian cherry to animals with streptozotocin-induced DM significantly reduced the content of ROS in blood leukocytes. The impairment of the enzymatic defense system in blood leukocytes of rats with diabetes was manifested in a decrease in the activity of SOD, CAT, GPx, and GR. Oral administration of the extract of yellow fruits of the cornelian cherry caused a significant increase in the activity of antioxidant enzymes.

\section{COMPLIANCE WITH ETHICAL STANDARDS}

Conflict of Interest: The authors declare that the research was conducted in the absence of any commercial or financial relationships that could be construed as a potential conflict of interest.

Human Rights: This article does not contain any studies with human subjects performed by the any of the authors.

Animal studies: All institutional, national and institutional guidelines for the care and use of laboratory animals were followed.

1. Asgary S., Rafieian-Kopaei M., Shamsi F., Najafi S., Sahebkar A. Biochemical and histopathological study of the anti-hyperglycemic and anti-hyperlipidemic effects of cornelian cherry (Cornus mas L.) in alloxan-induced diabetic rats. Journal of Complementary and Integrative Medicine, 2014; 11(2): 63-69.

Crossref $\bullet$ PubMed $\bullet$ Google Scholar

2. Bayram H.M., Ozturkcan Arda S. Bioactive components and biological properties of cornelian cherry (Cornus mas L.): A comprehensive review. Journal of Functional Foods, 2020; 75 : 104252.

Crossref $\bullet$ Google Scholar

3. Bila I., Dzydzan O., Brodyak I., Sybirna N. Agmatine prevents oxidative-nitrative stress in blood leukocytes under streptozotocin-induced diabetes mellitus. Open Life Sciences, 2019; 14: 299-310.

Crossref $\bullet$ Google Scholar

4. Dzydzan O., Bila I., Kucharska A. Z., Brodyak I., Sybirna N. Antidiabetic effects of extracts of red and yellow fruits of cornelian cherries (Cornus mas L.) on rats with streptozotocin-induced diabetes mellitus. Food Funct., 2019; 10(10): 6459-6472.

Crossref $\bullet$ PubMed $\bullet$ Google Scholar

5. Dzydzan O., Brodyak I., Sokót-Łętowska A., Kucharska A.Z., Sybirna N. Loganic acid, an iridoid glycoside extracted from Cornus mas $L$. fruits, reduces of carbonyl/oxidative stress biomarkers in plasma and restores antioxidant balance in leukocytes of rats with streptozotocininduced diabetes mellitus. Life (Basel), 2020; 10(12): 349.

Crossref $\bullet$ PubMed $\bullet$ PMC $\bullet$ Google Scholar

6. Ferents I.V., Brodyak I.V., Lyuta M.Ya., Burda V.A., Sybirna N.O. Suppressive effect of agmatine on genetically programmed death of leukocytes in a diabetes model. Cytol. Genet., 2016; 50(4): 241-250.

Crossref • Google Scholar

ISSN 1996-4536 (print) • ISSN 2311-0783 (on-line) • Біологічні Студії / Studia Biologica • 2021 • Том 15 / № 1 • С. 15-26 
7. Goldberg D.M., Spooner R.J. Glutathione Reductase. In methods of enzymatic analysis, 3rd ed.; Bergmeyer H.U., Bergmeyer J., GraBI M., Eds.; Verlag Chemie: Weinheim, Germany, 1983: 258-265.

Google Scholar

8. Góth $L$. A simple method for determination of serum catalase activity and revision of reference range. Clinica Chimica Acta, 1991; 196(2-3): 143-151.

Crossref $\bullet$ PubMed $\bullet$ Google Scholar

9. Graves D.T., Kayal R.A. Diabetic complications and dysregulated innate immunity. Frontiers in Bioscience, 2008; 13: 1227-1239.

Crossref $\bullet$ PubMed $\bullet$ PMC $\bullet$ Google Scholar

10. Ighodaro O.M., Akinloye O.A. First line defence antioxidants-superoxide dismutase (SOD), catalase (CAT) and glutathione peroxidase (GPX): Their fundamental role in the entire antioxidant defence grid. Alexandria Journal of Medicine, 2018; 54(4): 287-293.

Crossref $\bullet$ Google Scholar

11. Kakkar P., Das B., Viswanathan P.N. A modified spectrophotometric assay of superoxide dismutase. Indian Journal of Biochemistry \& Biophysics, 1984; 21(2): 130-132.

PubMed • Google Scholar

12. Limón-Pacheco J., Gonsebatt M.E. The role of antioxidants and antioxidant-related enzymes in protective responses to environmentally induced oxidative stress. Mutation Research/ Genetic Toxicology and Environmental Mutagenesis, 2009; 674(1-2): 137-147. Crossref $\bullet$ PubMed $\bullet$ Google Scholar

13. Lowry O.H., Rosebrough N.J., Farr A.L., Randall R.J. Protein measurement with the Folin phenol reagent. Journal of Biological Chemistry, 1951; 193(1): 265-275.

Crossref $\bullet$ PubMed $\bullet$ Google Scholar

14. Marrocco I., Altieri F., Peluso I. Measurement and clinical significance of biomarkers of oxidative stress in humans. Oxidative Medicine and Cellular Longevity, 2017; 2017: 6501046. Crossref $\bullet$ PubMed $\bullet$ PMC $\bullet$ Google Scholar

15. Matough F.A., Budin S.B., Hamid Z.A., Alwahaibi N., Mohamed J. The role of oxidative stress and antioxidants in diabetic complications. Sultan Qaboos University Medical Journal, 2012; 12(1): 5-18.

Crossref • PubMed • PMC • Google Scholar

16. Mclennan S.V., Heffernan S., Wright L., Rae C., Fisher E., Yue D.K., Turtle J.R. Changes in hepatic glutathione metabolism in diabetes. Diabetes, 1991; 40(3): 344-348.

Crossref $\bullet$ PubMed $\bullet$ Google Scholar

17. Melekh B., Ilkiv I., Lozynskyi A., Sklyarov A. Antioxidant enzyme activity and lipid peroxidation in rat liver exposed to celecoxib and lansoprazole under epinephrine-induced stress. Journal of Applied Pharmaceutical Science, 2017; 7(10): 94-99.

Crossref • Google Scholar

18. Moldovan B., David L. Bioactive flavonoids from Cornus mas L. fruits. Mini-Reviews in Organic Chemistry, 2017; 14(6): 489-495.

Crossref • Google Scholar

19. Newsholme P., Cruzat V.F., Keane K.N., Carlessi R., De Bittencourt Jr P.I.H. Molecular mechanisms of ROS production and oxidative stress in diabetes. Biochemical Journal, 2016; 473(24): 4527-4550.

Crossref $\bullet$ PubMed $\bullet$ Google Scholar

20. Nimse S.B., Pal D. Free radicals, natural antioxidants, and their reaction mechanisms. RSC Advances, 2015; 5: 27986-28006.

Crossref $\bullet$ Google Scholar

21. Ozougwu J.C., Obimba K.C., Belonwu C.D., Unakalamba C.B. The pathogenesis and pathophysiology of type 1 and type 2 diabetes mellitus. Journal of Physiology and Pathophysiology, 2013; 4(4): 46-57.

Crossref $\bullet$ Google Scholar

ISSN 1996-4536 (print) • ISSN 2311-0783 (on-line) • Біологічні Студії / Studia Biologica • 2021 • Том 15 / № 1 • C. 15-26 
22. Patel H., Chen J., Das K.C., Kavdia M. Hyperglycemia induces differential change in oxidative stress at gene expression and functional levels in HUVEC and HMVEC. Cardiovasc Diabetol, 2013; 12: 142.

Crossref $\bullet$ PubMed $\bullet$ PMC $\bullet$ Google Scholar

23. Pavelescu L.A. On reactive oxygen species measurement in living systems. Journal of Medicine and Life, 2015; 8 (Spec Issue): 38-42.

PubMed • PMC • Google Scholar

24. Rains J.L., Jain S.K. Oxidative stress, insulin signaling and diabetes. Free Radical Biology and Medicine, 2011; 50(5): 567-575.

Crossref $\bullet$ PubMed $\bullet$ PMC $\bullet$ Google Scholar

25. Rolo A.P., Palmeira C.M. Diabetes and mitochondrial function: role of hyperglycemia and oxidative stress. Toxicology and Applied Pharmacology, 2006; 212(2): 167-178.

Crossref $\bullet$ PubMed $\bullet$ Google Scholar

26. Rubattu S., Forte M., Raffa S. Circulating leukocytes and oxidative stress in cardiovascular disease: a state of the art. Oxidative Medicine and Cellular Longevity, 2019; 2019(16): 1-9. Crossref $\bullet$ PubMed $\bullet$ PMC $\bullet$ Google Scholar

27. Schmoch T., Uhle F., Siegler B.H., Fleming T., Morgenstern J., Nawroth P.P., Weigand M.A., Brenner $T$. The glyoxalase system and methylglyoxal-derived carbonyl stress in sepsis: glycotoxic aspects of sepsis pathophysiology. Int J Mol Sci, 2017; 18(3): 657.

Crossref $\bullet$ PubMed $\bullet$ PMC $\bullet$ Google Scholar

28. Soltani R., Gorji A., Asgary S., Sarrafzadegan N., Siavash M. Evaluation of the effects of Cornus mas L. fruit extract on glycemic control and insulin level in type 2 diabetic adult patients: A randomized double-blind placebo-controlled clinical trial. Evidence-Based Complementary and Alternative Medicine, 2015; 2015: 740954.

Crossref • PubMed • PMC • Google Scholar

29. Sybirna N.O., Hachkova G. Ya., Brodyak I.V., Sybirna K.A., Khokhla M.R., Sabadashka M.V. Functional biochemistry. Ed. N.O. Sybirna. Lviv: Ivan Franko National University of Lviv, 2018. 644 p. (Series "Studia Biologica"). (In Ukrainian)

30. Zdioruk M., Barska M., Brodyak I., Vovk O., Urbanovich A., Sybirna N. Influence of wortmanin on agregation ability of neutrophylic granulocytes under type 1 diabetes mellitus. Studia Biologica, 2009; 3(2): 133-140. (In Ukrainian)

Crossref $\bullet$ Google Scholar

31. Zdioruk M., Brodyak I., Sybirna N. Participation of PI-3'-kinase signaling pathway in determining structural and functional state of leukocyte membranes under type 1 diabetes mellitus.

Studia Biologica, 2011; 5(1): 85-96. (In Ukrainian)

Crossref $\bullet$ Google Scholar

32. Zhang P., Li T., Wu X., Nice E.C., Huang C., Zhang Y. Oxidative stress and diabetes: antioxidative strategies. Frontiers of Medicine, 2020; 14(5): 583-600.

Crossref $\bullet$ PubMed $\bullet$ Google Scholar

\title{
АНТИОКСИДАНТНИЙ ЕФЕКТ ЕКСТРАКТУ ЖОВТИХ ПЛОДІВ ДЕРЕНУ СПРАВЖНЬОГО (CORNUS MAS L.) В ЛЕЙКОЦИТАХ КРОВІ ЩУРІВ ЗА СТРЕПТОЗОТОЦИН-ІНДУКОВАНОГО ЦУКРОВОГО ДІАБЕТУ
}

\author{
М. Б. Сенів ${ }^{1}$, О. В. Дзидзан', І. В. Бродяк*1, А. З. Кухарська², Н. О. Сибірна \\ ${ }^{1}$ Львівський національний університет імені Івана Франка \\ вул. Грушевського, 4, Львів 79005, Україна \\ ${ }^{2}$ Вроилавський університет природничих наук \\ J. Chełmońskiego 37/41, 51-630 Вроилав, Польща \\ *Кореспондуючий автор e-mail: iryna.brodyak@Inu.edu.ua
}

ISSN 1996-4536 (print) • ISSN 2311-0783 (on-line) • Біологічні Студії / Studia Biologica • 2021 • Том 15 / № 1 • С. 15-26 
Обґрунтування. За цукрового діабету стан хронічної гіперглікемії та інтенсифріковані метаболічні шляхи перетворення глюкози призводять до утворення в надмірній кількості активних форм оксигену та розвитку оксидативного стресу. Для запобігання метаболічним, структурним і функціональним порушенням в організмі за діабету вчені проводять пошук нових препаратів на основі рослинної сировини. Здавна відомо, що фрукти та овочі є джерелами біологічно активних речовин, що позитивно впливають на здоров'я людини. Жовті плоди дерену справжнього (Cornus mas L.) містять значну кількість речовин (іридоїди, френольні кислоти і флавоноїди), властивості, біологічні ефекти й механізм дії яких $є$ не до кінця з'ясованими. Тому метою роботи було дослідити вплив екстракту жовтих плодів дерену справжнього на рівень активних форм оксигену й активність ензимів антиоксидантного захисту в лейкоцитах крові щурів зі стрептозотоцин-індукованим цукровим діабетом.

Матеріали та методи. Експериментальний цукровий діабет у щурів індукували внутрішньочеревним введенням стрептозотоцину, розвиток якого контролювали за вмістом глюкози у крові. Починаючи з 10-го дня від моменту індукції діабету тваринам вводили екстракт жовтих плодів дерену справжнього у дозі 20 мг/кг маси тіла впродовж 14 днів. В останній день експерименту проводили забір крові, виділяли лейкоцити і визначали вміст активних форм оксигену й активність ензимів антиоксидантного захисту. Статистичний аналіз отриманих результатів проводили за допомогою програми MS Excel-2013.

Результати. За стрептозотоцин-індукованого цукрового діабету в лейкоцитах тварин підвищується вміст активних форм оксигену та знижується активність антиоксидантних ензимів. Пероральне введення екстракту жовтих плодів дерену справжнього діабетичним тваринам покращує антиоксидантний статус лейкоцитів, на що вказує зростання активності супероксиддисмутази, каталази, глутатіонпероксидази та глутатіонредуктази разом зі зниженням рівня внутрішньоклітинних активних форм оксигену.

Висновки. Екстракт жовтих плодів дерену справжнього (Cornus mas L.) відновлює баланс між прооксидантами й антиоксидантною системою захисту в лейкоцитах щурів зі стрептозотоцин-індукованим цукровим діабетом. Такі результати можуть представляти екстракт жовтих плодів дерену як один із рослинних компонентів у розробці нових препаратів, які коригуватимуть метаболічні та функціональні порушення в лейкоцитах за діабету.

Ключові слова: екстракт жовтих плодів дерену справжнього, цукровий діабет, активні форми оксигену, ензими антиоксидантного захисту, лейкоцити

Revision / Доопрацьовано 16 February, 2021
Accepted / Прийнято 17 March, 2021
Published / Опубліковано 31 March, 2021 